\title{
28. A semiotic observation of narrative trajectories in Madonna in a Fur Coat by canonical narrative schemas
}

\section{Orhun BÜYÜKKARCI ${ }^{1}$}

APA: Büyükkarcl, O. (2021) A Semiotic Observation of Narrative Trajectories in Madonna in a Fur Coat by Canonical Narrative Schemas. RumeliDE Dil ve Edebiyat Araştırmaları Dergisi, (0̈9), 345-363. DOI: 10.29000/rumelide.984799.

\begin{abstract}
This study combines semiotic theory with Turkish literature in implementation on one of Sabahattin Ali's well-known novels, Madonna in a Fur Coat. From the ideas of C. S. Peirce and Ferdinand de Saussure have many semiotic branches derived, one of which is the so-called literary or narrative semiotics that deals with the unfolding of narrative structures and the signification of literary works under the leadership of A. J. Greimas. Literary semiotics postulates the idea that a narrative should be analyzed in three meaning layers: discursive, narrative, and deep-abstract levels. Accordingly, the primary purpose of this study is to reveal the narrative organization of Sabahattin Ali's novel, Madonna in a Fur Coat, employing canonical narrative schema, which is one of the analysis tools of literary semiotics. These actors are the unnamed narrator, Raif Efendi, Maria Puder, Raif Efendi's father and husbands of his sisters, all of whom have their own goals. Besides, unfolding the narrative trajectories of these actors will help formulate narrative level analysis on a literary work in a semiotic perspective. The study is composed of three parts. In the introduction part, the aims, method and scope of the study will be presented. In the second part, the narrative level analysis of the novel takes place considering the actors' trajectories. Lastly, in the conclusion part, the study results have been discussed under the titles of 'the temporal hierarchy and relationship between trajectories', 'cognitive senders', 'the trajectories ending with success vs failure', 'the key events that bridges the trajectories'. It is believed that this study will help readers gain insight into three aspects: Sabahattin Ali's authorship skills in creating fiction, the structural status of Madonna in a Fur Coat, and one possible application of the literary semiotic approach.
\end{abstract}

Keywords: Semiotics, canonical narrative schema, Sabahattin Ali, Madonna in a Fur Coat, narrative level analysis

\section{Anlatı șemaları aracılığıyla Kürk Mantolu Madonna'da anlatı izlemlerinin göstergebilimsel bir gözlemi}

Öz

Bu çalışma, göstergebilim kuramını ve Türk edebiyatını Sabahattin Ali'nin en tanınmış eserlerinden, Kürk Mantolu Madonna üstünde bir uygulamada birleştirmektedir. Çağdaş göstergebilim temellerini C. S. Peirce ve Ferdinand de Saussure'den alır. Bu iki filozofun görüşlerinden birçok göstergebilim dalı türemiştir ve bunlardan biri de A. J. Greimas'ın öncülüğünde, anlatısal yapıları ortaya çıkarmakla ve yazınsal eserlerin anlamlandırılmasıyla ilgilenen yazınsal-anlatısal göstergebilim dalıdır. Yazınsal göstergebilim bir anlatının, söylemsel, anlatısal ve derin yapı olmak üzere üç düzeyde incelenmesi gerektiği fikrini varsayar. Buna bağlı olarak, bu çalıșmanın birincil amacl, yazınsal göstergebilimin çözümleme aygıtlarından biri olan anlatı şemalarını kullanarak Sabahattin Ali'nin Kürk Mantolu

1 Dr. Öğr. Üyesi, Mardin Artuklu Üniversitesi, Yabancı Diller Yüksekokulu, Mütercim-Tercümanlık Bölümü, İngilizce ABD (Mardin, Türkiye). orhunbuyukkarci@artuklu.edu.tr, ORCID ID: 0000-0003-2808-2274 ([Araştırma makalesi, Makale kayıt tarihi: 25.07.2021-kabul tarihi: 20.08.2021; DOI: 10.29000/rumelide.984799]

Adres | Address

RumeliDE Dil ve Edebiyat Araşturmalar Dergisi $\quad$ RumeliDE Journal of Language and Literature Studies

Osmanağa Mahallesi, Mürver Çiçeği Sokak, No:14/8 Osmanağa Mahallesi, Mürver Çiçeği Sokak, No:14/8

Kadıköy - İSTANBUL / TÜRKIYE 34714 Kadıköy - ISTANBUL / TURKEY 34714

e-posta: editor@rumelide.com e-mail: editor@rumelide.com

tel: +90 $5057958124,+902167730616$ phone: +90 505 7958124, +90 2167730616 
A semiotic observation of narrative trajectories in Madonna in a Fur Coat by canonical narrative schemas / 0. Büyükkarcı (pp. 345363)

\begin{abstract}
Madonna romanının anlatısal düzenini ortaya çıkarmaktır. Bunu yapmanın söz konusu romandaki ana aktörlerin anlatı izlemleri hakkında açık bilgiler vereceğine inanılmaktadır. Bu aktörler sırasıyla isimsiz anlatıcı, Raif Efendi, Maria Puder ve Raif Efendi'nin ailesidir ve hepsinin anlatı içinde ulaşmak istediği kendi hedefleri vardır. Buna bağlı olarak, bu aktörlerin anlatı izlemlerini ortaya çıarmak, göstergebilimsel bakış açısıyla bir edebi eserin anlatı düzeyi incelemesinin netleştirilmesine de yardımcı olacaktır. Çalışma üç bölümden oluşmaktadır. Giriş kısmında, çalışmadaki göstergebilimsel yönteme dair bilgi verilmiştir, ikinci kısımda ise romanın anlatı düzeyi incelemesi yer almaktadır. Son olarak sonuç bölümünde romanın anlatı düzenine yönelik elde edilen bilgiler 'zamansal hiyerarşi ve anlatı izlemleri arasındaki ilişkiler', 'bilişsel göndericiler', 'başarı ve başarısızlıkla biten izlemler' ve 'izlemler arasında köprü kuran anahtar olaylar' başlıkları altında tartışılmıştır. Bu çalışmanın okuyucuların üç noktayı kavramada yardımcı olacağına inanılmaktadır: Sabahattin Ali'nin kurgu oluşturmadaki yazarlık becerisi, Kürk Mantolu Madonna'nın yapısal durumu ve son olarak yazınsal göstergebilim yaklaşımının muhtemel bir uygulaması.
\end{abstract}

Anahtar kelimeler: Göstergebilim, anlatı șeması, Sabahattin Ali, Kürk Mantolu Madonna, anlatı düzeyi çözümlemesi

\title{
1. Introduction: Preliminary remarks
}

Madonna in a Fur Coat (Ali, 1943) was first published "in a series of 48 episodes in Hakikat Newspaper between the years 1940-1941" (Bezirci, 2007, p. 204). Its author, Sabahattin Ali, is one of the prominent writers of Turkish literature and has remained popular with his "social realist" works (Moran, 2001, pp-2223; Okur, 2017, p.93). Accordingly, this study analyzes the narrative organization of Sabahattin Ali's wellknown work, Madonna in a Fur Coat (2017), with the analysis tools of literary semiotics. Under the leadership of Algirdas Julien Greimas, the Paris School of Semiotics purports to find the scientific ways of dealing with anything concerning "meaning and signification" (Landowski, 2015, p.84; Yücel, 2001, p.10), which is why Greimas named this movement "not as a science but a scientific project" (1989, p. 539). That Paris School chose narrative texts as the primary implementation area of their ever-developing theory since the 1960s makes this enterprise be called 'literary semiotics' in time. With its terminology, analysis tools and approach towards narratives, literary semiotics can be affirmed as "one of the most productive branches of structuralism" (Yücel, 2015, p.204). As its name signifies, the overall objectives of structuralist thought are "to unfold the internal meaning and the inner relations between constructive elements of a unit" (Vardar, 2001, p.11, Yücel, 2015) and “to analyze this unit synchronically as a system in itself” (Yüksel, 1995, p. 13). These principles apply to literary semiotics, making it possible to examine the collided narrative courses of story actors in Sabahattin Ali's book.

The reason for choosing Madonna in a Fur Coat ${ }^{2}$ as the text to analyze for this study underlies the fact that although there is already a great deal of academic research bringing criticism and diverse realist perspectives into the novel's relationship with real-life situations (Karakuş, 2010), few studies are aspiring to investigate its inner structures. Moreover, these structuralist studies comprise the analysis of the novel in the light of text linguistics (Hirik, 2020) or the narratorial position of the narrator concerning modality (Uzdu et al., 2018). Still, no study was found to have analyzed the novel in question from purely the perspective of literary semiotics, making such a study spring up. Thus, it is strongly believed that such an analysis of the narrative structure will provide helpful insight to understand one of the formative elements of the novel, and it is supposed with this study that the number of semiotic studies on the masterpieces of

For the analysis in this study, the 84th impression of the book, published in Turkish by Yapı Kredi in 2017, is used. All translations in the study are my own.

RumeliDE Dil ve Edebiyat Araştırmalar Dergisi Osmanağa Mahallesi, Mürver Çiçeği Sokak, No:14/8 Kadıköy - ISTANBUL / TÜRKIYE 34714 e-posta: editor@rumelide.com tel: +90 505 7958124, +902167730616

Address

RumeliDE Journal of Language and Literature Studies

Osmanağa Mahallesi, Mürver Çiçeği Sokak, No:14/8

Kadıköy - ISTANBUL / TURKEY 34714

e-mail: editor@rumelide.com

phone: +90 5057958124 , +90 2167730616 
Turkish literature will increase. However, the scarcity of the structural studies on the novel is not the only motive for this paper. There are two others: the former is the postulation that literary semiotics is an appropriate methodology that can best fit the objectives of both this study and of possible others seeking for structural relations by formulating the narrative organization, and thus helping unfold the signification of a text. The latter is the synchronic rise of literary semiotics with practical studies of Paris School in Europe, and in Turkey with Tahsin Yücel, "whose work (L'Imaginaire de Bernanos, his doctoral dissertation) was largely interpreted and criticized" (Yücel, 1999, p. 24) by Greimas in the conclusion part of his initial work Semantic Structurale (1966). If I may say so, this fact should lead us to conceive why and how this study brings together literary semiotics and Madonna in a Fur Coat, both of whose very first practitioner and the author are from Turkey.

As a priority, there is a need for further clarification on the limits of the study, and so it will provide information on how much of the literary semiotic approach will be implemented on how many of the structural units of the novel and the justifications for doing so. As stated earlier, the analysis of the novel is limited to the narrative organization, and as the title suggests, the narrative trajectories of the main actors in the novel. The limitedness of the research area is due to two factors, the profoundness of the semiotic methodology and the length of the target text. It is a fact that Greimas (Greimas \& Courtes, 1982), as the founding father of the theory, postulates the narrative semiotic analysis should cover three dimensions, which are respectively "discoursivization" (pp. 85-86), "narrativity" (pp. 208-210) and "deep structures" (pp. 69-70). All of those titles require the separate analysis of three meaning layers with many subparameters to be investigated in themselves. For instance, when we have a look at Greimas's work, Maupassant: The Semiotics of Text (1988), "which is one of the most accomplished samples of literary semiotic applications" (Yücel, 2012, p. 97), it can easily be seen that Greimas analyzed the five-page long Maupassant story "Deux Amis" in a nearly 250-page long book. Additionally, when we check the other studies adopting the literary semiotic approach to the investigation of a given artwork, we can observe that either the chosen text or its parts to be analyzed determines the scope of the study. For instance, while the applications of a complete version of semiotic analysis are compatible with the short stories and tales (Kalelioglu, 2018b; Martin \& Ringham, 2000, pp. 145-166, Martin \& Ringham, 2006, pp. 254-275; Büyükkarcl \& Bulut, 2018; Rifat, 2011, pp. 121-142; Yücel, 2014, pp. 199-216; Rifat, 2014, pp. 115-133), the partial applications of the methodology are generally observed to be performed on the novels or longer narratives (Öztokat, 2005, pp. 137-150). Lastly, however, as far as the novels are concerned, the scope of a complete version analysis can generally result in the flourishing of lengthy books (Kalelioğlu, 2020; Günay, 2018; Kalelioğlu, 2018a; Budniakiewicz, 1992). So, it can concisely be stated that only a narrative level analysis will be more reasonable for the article's scope when considering the number of details for both the method and target text.

Some other questions await answers to account for how and by what means the narrative analysis will be fulfilled in this study, and additionally, what benefit the reader will get after such investigation into the novel's narrative dimension. The primary aim of the narrative level analysis is to depict the significant transformation of actants (actors-characters), which is vital to understand "the narrative syntax" of a text (Kalelioğlu, 2020, p. 14). There are two main instruments used for this depiction. "Keeping in mind the differences between them" (Hebert, 2020, pp.108-109), these tools are respectively the actantial schema, which serves to indicate the roles of actants in a narrative; the other is the canonical narrative schema, a tool for facilitating the observation of transformational phases that an actant undergoes throughout the narrative. Greimas and Courtes note (1982) that this schema "serves as a point of departure for understanding the organizing principles of all narrative discourses" (p. 204). This applies to this study as well since the canonical narrative schema is the main instrument to be utilized for depicting the narrative

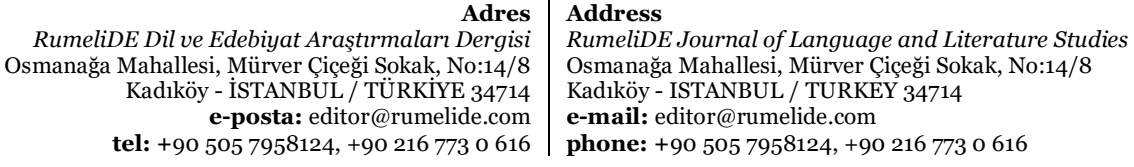


A semiotic observation of narrative trajectories in Madonna in a Fur Coat by canonical narrative schemas / 0. Büyükkarcı (pp. 345363)

organization of Madonna in a Fur Coat, revealing the positive and negative interrelations between the narrative trajectories of five main actors, respectively the unnamed narrator, Raif Efendi, Maria Puder and Raif Efendi's father and his sisters' husbands. Last but not least, doing all this in this study, I mean the formulation, and thus, concretizing the novel's narrative grammar, will provide the reader with valuable insight into three aspects: first, Sabahattin Ali's authorship skills in the creation of fiction, second, one possible application model of semiotics, and lastly, the structural state of the text itself.

\section{Analysis of the Trajectories}

Before starting the analysis, it is necessary to give a short information on the working principles of canonical narrative schema, which I believe will facilitate understanding the subsequent procedures. As noted in the introduction part, canonical narrative schema comprises the transformational phases of actors within a narrative, and it indicates stages of the quest that actors undergo in a narrative: these are, "manipulation", "competence", "performance" and "sanction" (Bronwen \& Martin, 2000, p. 32; Kıran \& Kiran, 2018, p. 434; Kıran \& Kıran, 2011, 304). As Greimas and Courtes states (1982), these stages are "the repetition of three tests-qualifying, decisive and glorifying which appeared as the regularity, located upon the syntagmatic axis, that revealed the existence of a canonical narrative schema" (p. 204). Whether a character or noncharacter, the sender directs the subject towards an object at the manipulation stage. This is the initiating "contract" phase of a trajectory, "established from the beginning between the sender and the subject" (Greimas, 1982, p. 60). The competence stage indicates the phase in which the subject gains the necessary competence, skill, knowledge or material to fulfil the mission. "Knowing-how-to-do", "being-able-to-do", "having-to-do", "wanting-to-do" are the primary modalities to be observed (Kalelioğlu, 2020, p. 127). The performance stage is the one that comprises the fulfilment of action with the obtained material at the competence stage. The primary modalities are as follows: "to-do". This stage is important in that the subject can either achieve or fail the quest. In the sanction phase, the outcome of a quest is declared to the reader, and the sender is informed about the result. As Hebert suggests (2020), the sender's "epistemic judgment determines whether performance conforms to the implicit or explicit contract that was made during the manipulation stage" (p. 114).

\subsection{The unnamed narrator}

Madonna in a Fur Coat can be said to subsume two interdependent stories whose narrators are different. In the first part of the book (Ali, 2017, pp. 11-46), the unnamed narrator recounts his thoughts and a given piece of his life to the audience. In the second part, however, the audience is left to Raif Efendi's narration of his private part of life through his notebook (pp. 46-160). The nameless narrator begins speaking about Raif Efendi, "who is the most effective person in his life" (p. 11), and when and how he came to know him. All of what he tells to the audience can be summed up to serve the purpose of giving information about how Raif Efendi became a person of the narrator's interest. It can be seen from the beginning of the story that the narrator implicates that he is narrating the story to introduce Raif Efendi and what impact he had on his life. After recounting "how he was dismissed from the bank he worked and looked for a job for a long time" (pp. 12-13), then "how he coincided with Hamdi on the street" (pp. 13-14), and "that Hamdi provided him with a follow-up job" (p. 17), the narrator encounters Raif Efendi and gives the very first impressions on him: "shortly cut, thin hair with a wrinkled skin through his tiny ears to the dewlap, sometimes rising his head as if thinking of the word he failed to find" (p. 18).

However, no relations can be said to promote between the narrator and Raif Efendi for days though they share the same office at work. This makes the narrator become disinterested in Raif Efendi. Because of his

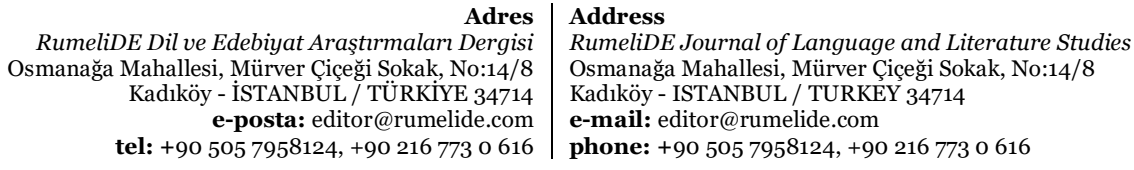


annoying daily routines such as his "lunchtime manner" (p. 18), "translation style of the documents" (p. 19), "secretly reading something that he called a novel in German" (p. 19-20), and his permanent senseless manner" (p. 21) never change. The narrator gradually becomes more intimate with the others at work and learns what they think about Raif Efendi and what kind of a person he is. All the others at work have a negative perception of Raif Efendi. They see him as "a slowpoke person who has to earn to look after a big family and doubtfully know a language" (p. 19). Nevertheless, what they say about Raif Efendi is understood to have missed the mark by an incident that the narrator witnessed.

One day, Hamdi enters the room the narrator and Raif Efendi were in and starts shouting at Raif Efendi "due to a belated letter translation from a Hungarian company" (p. 21). Raif Efendi remains still not uttering a word to Hamdi, although this delay was just because of the typists. After being back from requesting the typist to speed up the draft, Raif Efendi has his seat and silently starts drawing shapes on a small piece of paper with a smile on his face. Seeing how accurately the mini depiction of Hamdi with an open shouting mouth on the paper pictured, the narrator's thoughts on Raif Efendi start changing. He feels that Raif Efendi is not so lackadaisical a man to his environment and is aware of the personal characteristics of the people around him. Besides, this incident triggers the narrator's curiosity, as can be seen in his statement, "Raif Efendi has again been a suspenseful man for me" (p. 23). From this point on, it can be seen that the narrator's trajectory in the novel starts. This trajectory is shortly to know more about the man he works with at the same office, to tackle the mysterious inconsistency between Raif Efendi's actions and capacity to analyze the inner worlds of people around. Below is the canonical narrative schema depicting the narrator's phases of the steps from beginning to the end of the story.

Table 2.1: Canonical Narrative Schema of the Narrator's Trajectory

\begin{tabular}{|c|c|c|c|}
\hline $\begin{array}{l}\text { Manipulation } \\
\text { (Contract) }\end{array}$ & $\begin{array}{l}\text { Competence } \\
\text { (Qualifying Test) }\end{array}$ & $\begin{array}{l}\text { Performance } \\
\text { (Decisive Test) }\end{array}$ & $\begin{array}{l}\text { Sanction } \\
\text { (Glorifying Test) }\end{array}$ \\
\hline $\begin{array}{l}\text {-The desire to learn the } \\
\text { secret part of Raif Efendi's } \\
\text { life triggers the narrator (p. } \\
23 \text { ). } \\
\text {-He wants to learn the truth } \\
\text { about his identity (p. 24) }\end{array}$ & $\begin{array}{l}\text {-The narrator visits Raif } \\
\text { Efendi for illness (p. 24). } \\
\text {-Raif Efendi does not show } \\
\text { a timid manner to the } \\
\text { narrator (p. 34). } \\
\text {-The narrator insistently } \\
\text { asks for permission to read } \\
\text { Raif Efendi's notebook (p. } \\
\text { 44), and Raif Efendi allows } \\
\text { the narrator to read the } \\
\text { notebook (p. 45) }\end{array}$ & $\begin{array}{l}\text {-The narrator reads } \\
\text { Raif Efendi's notebook } \\
\text { till the end and learns } \\
\text { everything about his } \\
\text { past life (pp. 46-160). }\end{array}$ & $\begin{array}{l}\text {-The narrator learns of all } \\
\text { that happened in Raif } \\
\text { Efendi's life and states that } \\
\text { he understands what } \\
\text { caused him to be isolated } \\
\text { (p. 160). }\end{array}$ \\
\hline \multicolumn{4}{|c|}{ Modality } \\
\hline $\begin{array}{l}\text { Convincing/Directing } \\
\text { Wanting-to-do } \\
\text { Having-to-do }\end{array}$ & $\begin{array}{l}\text { Being-able-to-do/Wanting- } \\
\text { to-do } \\
\text { Knowing-how-to- } \\
\text { do/Having-to-do }\end{array}$ & To-do & $\begin{array}{l}\text { Knowing about } \\
\text { action/subject }\end{array}$ \\
\hline
\end{tabular}

As stated, the picture Raif Efendi drew has the narrator suspect him. He furtherly defines it with this statement, "I was sensing lots of contradictions with him despite the light blazing in my mind" (p. 23), "from now on every behaviour of Raif Efendi has attracted my attention, even the meaningless and immaterial ones" (p. 24). Deciding to solve Raif Efendi mystery, the narrator "makes use of any chances" (p. 24). It is possible to say that he proceeds to the next stage in his trajectory, the competence phase. This part of the

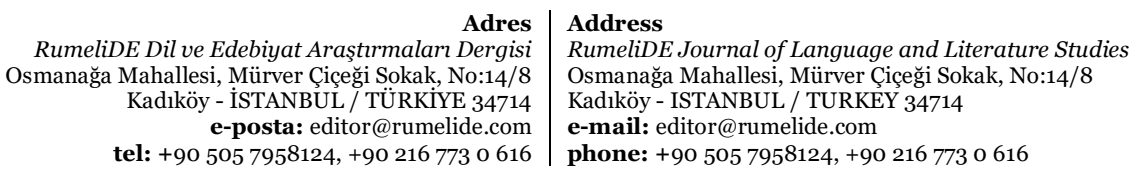


A semiotic observation of narrative trajectories in Madonna in a Fur Coat by canonical narrative schemas / 0. Büyükkarcı (pp. 345363)

narrative indicates the process of gaining what is necessary to achieve the quest. Thus, the narrator first has to be closer to Raif Efendi to learn his true identity. He first visits Raif Efendi's home to deliver both a translation document and get well soon wish to him. We can evaluate it as a chance for the narrator to be closer to Raif Efendi. However, the narrator's curiosity about him increases on each step, and he learns more about his life. In Raif Efendi's house, the narrator witnesses Raif's domestic life and knows details about the members of this house (p. 25-27). This visit to Raif Efendi at home during his illness was the first step and strengthened their friendship. However, Raif Efendi keeps the distance between the narrator and himself. Though some days "they together go out of work and drink coffee at Raif Efendi's house" (p. 27), they speak sweet nothings like the high prices in Ankara or the disorder of pavement in the neighbourhood. The narrator's visits to Raif Efendi's house gradually get more frequent, and he becomes pretty familiar with the house's inhabitants (pp. 28-33). Though not fully understands the reasons for Raif Efendi's introversion, the narrator achieves annihilating "Raif's shy and timid manner" (p. 34) against him. One day Raif Efendi gets sick again, but his illness is longer and more severe than the previous ones. The narrator constantly goes visiting and helping him. However, Raif Efendi's health status goes worse, and he understands he is to die soon. Then, he asks the narrator "to bring all of what remains in the drawer of the console at the office" (p. 40). Among them is Raif Efendi's special notebook "that he does not want the narrator to read but burn in the stove" (p. 43). The last thing that the narrator has to obtain is permission to read the notebook, which is the key to reach core information on Raif Efendi. Instructed to burn the notebook on the stove, the narrator harshly resists Raif Efendi and asks for permission to read the notebook. His insistence helps to persuade Raif Efendi, and the narrator, taking the essential key to learning Raif Efendi's past, completes the competence level in his trajectory. This can be seen in Raif Efendi and the narrator's statements, "read it, then you will see" (p. 45), "as soon as I heard this, I put the notebook into my pocket" (p. 45).

After taking leave from Raif Efendi's house kissing his hand, the narrator remains face to face with what he has followed for months. He has Raif Efendi's notebook in his hand and is on the edge of reaching the knowledge of his past life. It is shortly about what caused Raif Efendi to be so introverted as to be alienated from everyone at work and home. Between pages 46-160, Raif Efendi's notebook is read by the narrator until the end of the novel. Finally, the narrator declares it with the statement of "Raif Efendi's notebook ends with this. There are no further notes and records on other pages" (p. 160). This, in semiotic terms, indicates the ending of the performance stage. The narrator achieved his goal, and the last phase is the sanction in which this success is to be declared.

Raif Efendi undoubtedly recounts his own past life through his own words, but the narrator seemingly learns and declares all the facts about him. The narrator is perhaps the only person around Raif Efendi who knows the truths and why he became so isolated from everyone. For the narrator's trajectory, this is the sanction stage, and it is the last phase that subsumes announcing the outcome. The narrator, who truly understands Raif Efendi, asserts that "I do not feel like I lost Raif Efendi, but like have just found him" (p. 160), "although Raif Efendi wrote down on the notebook we could not have a chance to speak, I have talked all the night to him" (p. 160).

\section{2 "Raif Efendi"}

Raif Efendi is the main actor around whom the story circles. He is in front of the audience with two different identities in two different periods of his life. The first is his maturity recounted as an old, timid, introverted and dissocial person by the narrator. The second covers his youth time in which his experiences have a significant impact on the rest of his life. Raif Efendi is the narrator of his youth time, and only by the narrator's insistence is he persuaded that his notebook is read to learn all of what happened in his life

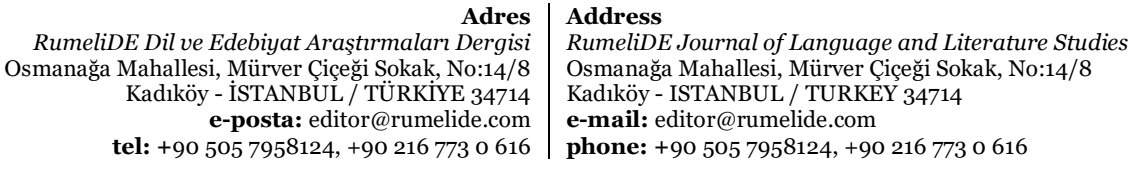


before. Thus, his narrative trajectory, the outcome of which is the key to his transformation, must be sought in the youth time that he recorded in his notebook. Raif Efendi's past life is full of losses and sorrow. However, "he wants to tell everything in turn from the beginning" (p. 46). Raif Efendi's father, "who is well off in the town they live" (p. 48), "decides to send him to Istanbul" (p. 48), then to "Germany to expertise on soap production."3 (p. 50) for they have a soap factory that Raif Efendi would one day run. Nevertheless, Raif Efendi idles there, telling lies to his father that "he is busy with language learning and will soon apply to a soap production facility" (p. 52). "Nearly one year has passed since he came to Germany" (p. 54), but he is still not fully busy with soap expertise. One day Raif Efendi accidentally finds himself in front of an art gallery. While rambling in the gallery, he gazes upon "a portrait of a woman in a fur coat" (p. 55). Raif Efendi is so stuck to this picture that "he can't help thinking he used to know her from the novels he has read since his childhood" (p.55) and watches it not move even though people are pushing him the right and left. Getting back to the hostel he has stayed, Raif Efendi skims through the magazine in which a commentary on the portrait and its painter, "Maria Puder" (p. 56), mentions them with an analogy to "Mother Mary" and "Madonna in a fur Coat" (p. 57). He incessantly "goes to the art gallery in the afternoon to see the painting of Madonna in a Fur Coat till the doors are to be closed" (p. 59). Raif's regular visits attract the attention of everyone. He so attentively observes the painting that he even does not realize it is the woman in and of the artwork that goes up to him and asks questions like, "do you wonder this painting a lot? You are watching it every day" (p. 60). This belief comes true. Though he decides not to go to the gallery again and return to his hometown, he sees Maria Puder one day, "walking with a sorrowful, bored expression on her face as if she were not aware of who is around" (p. 63). Raif Efendi decides to eat dinner out the next day and goes to "Nollendorf Square where he met Madonna in a Fur Coat the other day" (p. 67). It can be argued that his trajectory initiates on this point, the point on which he understands he can see again what he has constantly been thinking of. The manipulator or the sender is the love or the attraction emerging when Raif Efendi saw the painting. He got face to face with her alive and wants to find another trace of her, which is why he comes to the place he saw her. Below is the canonical narrative schema of Raif Efendi's trajectory depicting the phases in which he underwent transformations. This painting makes Raif believe "it is not only possible for him to find the woman he has sought, but he is so close to her as well" (p. 62).

Table 2.2: Canonical Narrative Schema of Raif Efendi's Trajectory

\begin{tabular}{|c|c|c|c|}
\hline $\begin{array}{l}\text { Manipulation } \\
\text { (Contract) }\end{array}$ & $\begin{array}{l}\text { Competence } \\
\text { (Qualifying Test) }\end{array}$ & $\begin{array}{l}\text { Performance } \\
\text { (Decisive Test) }\end{array}$ & $\begin{array}{l}\text { Sanction } \\
\text { (Glorifying Test) }\end{array}$ \\
\hline $\begin{array}{l}\text {-Raif Efendi sees a portrait of a } \\
\text { woman in a fur coat and } \\
\text { cannot take his eyes from the } \\
\text { painting of Maria Puder and } \\
\text { stop thinking of her (p. 55). } \\
\text {-One night, he sees her on the } \\
\text { street (p. 63) and goes back to } \\
\text { the place to see her again (p. } \\
\text { 67). } \\
\text {-It is either the desire to steal } \\
\text { Maria's heart or Raif's love to } \\
\text { trigger his actions. }\end{array}$ & $\begin{array}{l}\text {-Raif Efendi sees } \\
\text { Maria again (p. 68) } \\
\text { and follows her to } \\
\text { the pub she works } \\
\text { at (p. 69). } \\
\text {-Maria greets Raif } \\
\text { in a friendly and } \\
\text { warm manner (p. } \\
\text { 72). } \\
\text {-Maria approaches } \\
\text { and starts a } \\
\text { dialogue with Raif } \\
\text { (p. 74). }\end{array}$ & $\begin{array}{l}\text {-Raif and Maria meet, } \\
\text { and they talk about } \\
\text { each other frankly (pp. } \\
\text { 89-105). } \\
\text {-They start meeting } \\
\text { every day (p.105). } \\
\text {-On New Year's Eve, } \\
\text { they have fun and sleep } \\
\text { (p. 110-117). But it not } \\
\text { enough for Maria to fall } \\
\text { in love with him, and } \\
\text { they break up (p. 120). } \\
\text { Raifs father dies } \\
\text { (p.137), and he has to }\end{array}$ & $\begin{array}{l}\text {-Raif coincides with Frau Van } \\
\text { Tiedermann in Ankara. He } \\
\text { learns all the truth about Maria. } \\
\text { After a short time giving birth to } \\
\text { her child, she died. She was } \\
\text { Raif's daughter as well. Raif } \\
\text { understands all what has } \\
\text { happened since he left Berlin } \\
\text { (pp. 155-156). }\end{array}$ \\
\hline
\end{tabular}

This incident seems very much like the main trajectory of Raif Efendi. However, Raif has never such an aim, and he confesses that he wants to see "Europe that he used to read through the novels" (p. 50). Therefore, this trajectory is considered Raif's father's trajectory in the following parts of the analysis.

Adres $\mid$ Address

RumeliDE Dil ve Edebiyat Araştırmaları Dergisi Osmanağa Mahallesi, Mürver Çiçeği Sokak, No:14/8 Kadıköy - ISTANBUL / TÜRKIYE 34714 e-posta: editor@rumelide.com tel: +90 505 7958124, +90 2167730616

RumeliDE Journal of Language and Literature Studies

Osmanağa Mahallesi, Mürver Çiçeği Sokak, No:14/8

Kadıköy - ISTANBUL / TURKEY 34714

e-mail: editor@rumelide.com

phone: +90 505 7958124, +90 2167730616 
A semiotic observation of narrative trajectories in Madonna in a Fur Coat by canonical narrative schemas / 0. Büyükkarcı (pp. 345363)

\begin{tabular}{|l|l|l|l|}
\hline & $\begin{array}{l}\text {-They decide to } \\
\text { become friends (p. } \\
\text { 77) and promise to } \\
\text { see each other } \\
\text { again tomorrow (p. } \\
84) .\end{array}$ & $\begin{array}{l}\text { be back in his } \\
\text { Mometown (p. 141). } \\
\text { Maria goes to Prag (p. } \\
\text {-The link between Raif } \\
\text { and Maria is broken. } \\
\text { Raif cannot hear from } \\
\text { her (p.145). }\end{array}$ & \\
& & & \\
& & & \\
& & & \\
\hline $\begin{array}{l}\text { Convincing/Directing } \\
\text { Wanting-to-do } \\
\text { Having-to-do }\end{array}$ & $\begin{array}{l}\text { Being-able-to-do } \\
\text { Wanting-to-do }\end{array}$ & To-do & \\
\hline
\end{tabular}

Raif Efendi starts waiting for Maria Puder at the same place in the hope that he might see her again. Although not knowing what to do even if he could see her, he keeps waiting and afterwards sees "someone approaching the street where he stands" (p. 68). He is sure that she is the woman, and for not to lose her again, he starts following her without being noticed. At the end of the pursuit, he detects the woman went into "Atlantic Casino" (p. 68) by confirming the man standing at the door. Raif Efendi, a timid man who has never had a relationship with a woman, unconsciously goes into the pub for having contact with her. Raif Efendi's contact, which he does not expect, for he does not think she would be able to remember him, is provided with a "friendly greeting" of Maria singing songs at the scene (p. 72). This incident, "which is enough for making Raif the happiest man of the world" (p. 73), is precisely what Raif Efendi has been awaiting. However, as for competence level, Raif further needs to talk to her "to improve friendship" (p. 73). Although Raif Efendi thinks it would be discourteous to expect a talk with her, this move comes from Maria too. She approaches the table Raif is sitting at and says first, "How are you doing", then has an opposite seat (p.74). Maria Puder behaves far more intimately to Raif than he thinks. Besides, her intimacy saves Raif Efendi, who knows nothing about starting a dialogue with Maria from big trouble. The conversation is a big step for Raif Efendi as they have learnt lots of details about each other. What they have shared are, for instance, that Maria was the woman who came nearby and "asked Raif what to find in this painting at the gallery" (p. 75), "she watched Raif observing her portrait" (p. 76), "she is 26" and "Raif is 24" (p. 76), both of them feel "lonely" (p. 77) and "may become friends" (p. 77) only by observing "the rules Maria established" (pp. 81-82). Besides, they promise to see each other "tomorrow afternoon at the same place they leave" (p. 84). This part precisely indicates that Raif has gained what is necessary to keep the connection to Maria at the competence level of his trajectory. He has met Maria and will be with her again the next day. From this point on, Raif is at the performance stage in which he expects to be closer to Maria Puder, to whom he has deep admiration.

What is next for Raif's trajectory is to have a place at the heart of Maria. In Raif's inner monologues, we can see that although "he knows nothing about her, he is sure she is the person he has sought and expected throughout his life" (p. 85). Raif further reflects his intriguing feelings against Maria in these statements: "she is certainly the person I need to live" (p.86), "I am impatient for depicting her my soul, all naked, without hiding anything" (p. 87). Raif is very sensitive to Maria and ultimately leaves himself to her

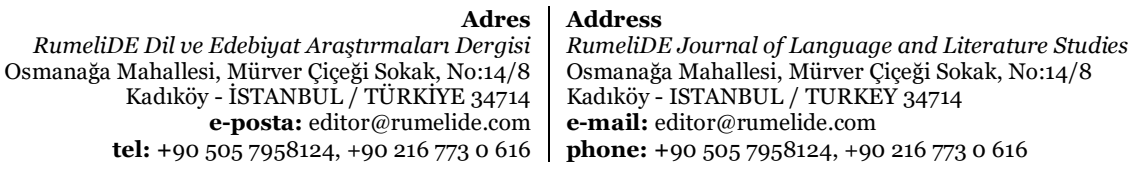


directions on the first date, saying, "I depend on you" (p. 90), "you precluded me from asking for nothing" (p.91). They first go in "a big garden with gratings" (p. 91), then decide to eat out "in a restaurant in the west part of the city" (p. 95). After a bit of silence, Maria starts her talk saying, "don't be offended with me, but I don't love you too" (p. 96), then she unburdens herself to Raif about her thoughts on male dominance, all of which brings about loneliness to her (pp. 96-102). Later, they decide to keep their chat in "Romanisches Kaffe" (p. 102) till 11.00 p.m. The day ends with Raif's accompany Maria to Atlantic Pub, where she works at nights, and one more appointment for a new date the next day and Maria's farewell kiss. The dates become regular, "they meet and walk around every day mostly in museums and art galleries" (p. 105), all of which are evaluated as "closeness of souls" by Raif (p. 105). Raif confesses he loves her, but Maria "does not give chances that will change their friendship into a different mode" (p.106) and continues to call Raif "my friend" (p.107). This calling indicates Raif has gained a preferable closeness to her but not a sense of love in her eyes. Besides, he cannot fully disclose his feelings to her because of "the fear of losing her" (108). On New Year's Eve, they decide to go to a place called "Europe" (p.111) on the opposite side of Anhalter Station. That night is magical for Raif because he has slept and woken up with her and "fulfilled all his desires" (p. 117). However, Maria behaves senselessly and calls Raif "my friend" again (p. 119). She says, "try hard as she may, she cannot fall in love with Raif" (p. 119) and "wants not to be with Raif till they both feel the need to see each other" (p. 120). Five days have passed, but Raif could not see Maria though he has gone to her working place. Raif learns that she has been ill and "was taken to Charite Hospital as she had no one to care for her" (p.127). Raif immediately goes to the hospital and looks after Maria for 25 days there. Afterwards, he keeps looking after her at home, and one day, Maria confesses that "she loves Raif too". This delayed declaration of love, says Maria, is "because of the people who secured the sense of trust from her" (p. 136). This is the most significant improvement that Raif has expected for a long time. They spend time together happily, but when Raif is back to the pension, he has stayed for one year, and he takes a telegraph: in it was written, "your father died, I sent the carfare, be here immediately" (p. 137). This incident reminds them of the fact that Raif "belongs to far afield where this telegraph comes from" (p. 137). They talk about the incident, and Maria decides to go to Prag before Raif leaves, saying, "whenever you call me, I will come", and afterwards, "wherever you call me, I will come" (p.140). When Raif is back in his hometown, he cannot see a welcome by his brothers in law and take the natural part of his father's legacy. He "often exchanges letters with Maria" (p.143), but after some time, he can neither "get responds to his letter from Maria nor can he hear from her" (p. 145). This shows the link between Raif and Maria is broken. At the same time, it means that Raif loses Maria, which indicates Raif fails to be happy with Maria.

The last phase of Raif's trajectory is the sanction in which his failure is declared. Raif recounts how he has lived without Maria and what he has done to get used to her absence. He thinks of many possibilities on the reasons for not to hear from her. He takes back the letters he has sent to Maria as she has been unresponsive. However, Raif has to wait for long years to learn why he cannot establish a connection with Maria. He occasionally implicates the importance of this fact, which obliges Raif to pen his memories. He sends letters to the pension owner to learn Maria's status from Frau Van Tiedermann, a relative of Maria that Raif lived at the same hotel in Berlin. However, in the response letter, the lady says, "Frau Van Tiedermann does not stay at the pension". Losing all his hopes, Raif understands all of what he has experienced in Germany was "nothing but dream and delusion" (p. 147). He marries his current wife, one of whose distant relative help Raif get a job in the company he works for now. Ten years have passed since Raif left Berlin and all that he lived, but one day "walking on the street, he is grabbed with his arm by someone" (p.150); she is Frau Tiedermann, Maria's relative. Both of them are pretty surprised and go somewhere to be able to talk more freely. Frau Tiedermann is not aware of Raif and Maria's relationship, but Raif is impatient to ask questions about her. Embarrassed by Raif's indirect questions, Frau Tiedermann says "that Maria died" (p.155), and she can tell what happened to her in detail. She continues to speak and says, "that she went to see Maria's

RumeliDE Dil ve Edebiyat Araşturmalar Dergisi $\quad$ RumeliDE Journal of Language and Literature Studies Osmanağa Mahallesi, Mürver Çiçeği Sokak, No:14/8 $\quad$ Osmanağa Mahallesi, Mürver Çiçeği Sokak, No:14/8 Kadıköy - ÍSTANBUL / TÜRKIYE 34714 Kadıköy - ISTANBUL / TURKEY 34714 e-posta: editor@rumelide.com e-mail: editor@rumelide.com tel: +90 505 7958124, +90 2167730616 phone: +90 505 7958124, +90 2167730616 
A semiotic observation of narrative trajectories in Madonna in a Fur Coat by canonical narrative schemas / 0. Büyükkarcı (pp. 345363)

mother when she heard that Maria died" (p.155), "that Maria's mother told her Maria felt some changes on her body and went to see a doctor" (p.155), "then, she learnt she was pregnant, but the doctors found this too risky for Maria due to her previous illness" (p.156), "However, Maria insisted on giving birth the child whose father she was not able to tell her mom" (p. 156). Hearing all these, Raif freezes up and cannot say anything. All he can do is to take a look at her daughter moving away on the bus. This is the declaration of the result of Raif's trajectory. Raif regrets having doubted Maria and understands all that has happened since he cannot hear from her and the shocking truth about his daughter against which he cannot do anything but pen them all in his notebook.

\section{3 “Maria Puder"}

Maria Puder is one of the main actors in the novel. Her story, that is, her narrative trajectory, cannot be separated from that of Raif. We get to know and have ideas about her course, in whose phases she transforms, by two primary sources of information. One of them is Raif's thoughts and interpretation of her personality, and the other is the directly reflected conversations that she makes with Raif. The second source can be more beneficial for observing her mindset, deducing her intention and concretizing her tendency within transformations as she is a forthcoming, self-confident, single-minded and strong woman. It is possible to suggest that her narrative trajectory gets started with two actions, one which is cognitive and the other is performative. The cognitive action comprises when she sees Raif at the art gallery in which she exhibits her painting and has some presuppositions on him. Seeing Maria's portrait, Raif freezes up and starts observing it for hours, and he repeats it "every afternoon until the doors of the gallery are closed" (p. 59). This man, even whose name Maria does not know, attracts her attention, and she goes up asking questions like "[D]o you wonder this portrait a lot? You come every day and observe it" (p. 60). However, this conversation annoys Raif, who understands that everyone has been aware of his strange behaviour and leaves the gallery without noticing who was the person asking questions, and he does not come back again. The performative action by which Maria is manipulated to decide to be friends with Raif is that she sees him again among the audience watching her. She "greets him with a warm manner" (p. 72), afterwards starts a dialogue with him at the pub where she works at nights. She says, "she has been curious about his staring the portrait" (p. 76) and finds his manner quite different from those of other men and confesses that "she is lonely too as if she could drown" (p. 77). Maria further states that she finds Raif quite different from other men, and "they can be friends" (p. 77). This indicates the initiation of her trajectory in which she seeks to eliminate her loneliness. She will confess in the further dialogues, finding the man she may experience true love with. The phases of Maria's trajectory are listed in the following table.

Table 2.3: Canonical Narrative Schema of Maria Puder's Trajectory

\begin{tabular}{|c|c|c|c|}
\hline $\begin{array}{l}\text { Manipulation } \\
\text { (Contract) }\end{array}$ & $\begin{array}{l}\text { Competence } \\
\text { (Qualifying Test) }\end{array}$ & $\begin{array}{l}\text { Performance } \\
\text { (Decisive Test) }\end{array}$ & $\begin{array}{l}\text { Sanction } \\
\text { (Glorifying Test) }\end{array}$ \\
\hline $\begin{array}{l}\text {-Maria sees Raif, who } \\
\text { observes her painting for } \\
\text { hours and wonder about } \\
\text { him a lot (p. 59). } \\
\text {-She is manipulated to } \\
\text { make friend with him by } \\
\text { the desire to find the right } \\
\text { man (p. 77). }\end{array}$ & $\begin{array}{l}\text {-After Maria decides to } \\
\text { make friend with Raif, } \\
\text { she asks him to } \\
\text { accompany her they } \\
\text { start to know each other } \\
\text { (p. 79). } \\
\text {-The next day, Maria } \\
\text { clearly states that she } \\
\text { cannot be lovers but } \\
\text { friends with Raif. } \\
\text { However, she continues }\end{array}$ & $\begin{array}{l}\text {-Maria starts showing } \\
\text { intimate behaviour to } \\
\text { Raif from time to time } \\
\text { (p. 109). } \\
\text {-On New Year's Eve, } \\
\text { they have intercourse } \\
\text { (p. 116). But Maria } \\
\text { cannot find love and } \\
\text { decide not to see each } \\
\text { other for some time (pp. } \\
\text { 118-120). }\end{array}$ & $\begin{array}{l}\text {-Maris stops sending letters to } \\
\text { Raif, and their connection is } \\
\text { broken. Frau Van Tiedermann } \\
\text { recounts all the incidents } \\
\text { about Maria. She says, "Maria } \\
\text { died at the time of her } \\
\text { daughter's birth without } \\
\text { telling anyone the name of her } \\
\text { daughter's father" (pp. 155- } \\
\text { 156). }\end{array}$ \\
\hline $\begin{array}{r}\text { RumeliDE Di } \\
\text { Osmanağa Maha } \\
\text { Kad } \\
\text { tel: }+\end{array}$ & $\begin{array}{l}\text { Adre } \\
\text { ve Edebiyat Araştırmalar Dergi } \\
\text { lesi, Mürver Çiçeği Sokak, No:14/ } \\
\text { xöy - İSTANBUL / TÜRKIYE } 3471 \\
\text { e-posta: editor@rumelide.cor } \\
\text { o 505 7958124, +90 } 216773061\end{array}$ & $\begin{array}{l}\text { Address } \\
\text { RumeliDE Journal of Langu } \\
\text { Osmanağa Mahallesi, Mürve } \\
\text { Kadıöy - ISTANBUL / TUR } \\
\text { e-mail: editor@rumelide.co } \\
\text { phone: +90 505 7958124, + }\end{array}$ & $\begin{array}{l}\text { ge and Literature Studies } \\
\text { Çiçeği Sokak, No:14/8 } \\
\text { EY } 34714 \\
\text { O } 216773 \text { o } 616\end{array}$ \\
\hline
\end{tabular}




\begin{tabular}{|c|c|c|c|}
\hline & $\begin{array}{l}\text { to be familiar with him } \\
\text { and tries to find ways of } \\
\text { loving him (pp. 96-109). }\end{array}$ & $\begin{array}{l}\text {-In the next few days, } \\
\text { Maria gets sick badly } \\
\text { and is taken to hospital. } \\
\text { Raif deals with all her } \\
\text { needs for days, and she } \\
\text { accepts that she is in } \\
\text { love with Raif (pp. 127- } \\
\text { 136). } \\
\text {-This does not last long. } \\
\text { Raif has to be back in } \\
\text { his hometown because } \\
\text { of his father's demise. } \\
\text { So this is the last time } \\
\text { she sees Raif (p. 140). }\end{array}$ & \\
\hline \multicolumn{4}{|l|}{ Modality } \\
\hline $\begin{array}{l}\text { Convincing/Directing } \\
\text { Wanting-to-do } \\
\text { Having-to-do }\end{array}$ & $\begin{array}{l}\text { Being-able-to-do } \\
\text { Wanting-to-do } \\
\text { Knowing-how-to-do } \\
\text { Having-to-do }\end{array}$ & To-do & Knowing about action/subject \\
\hline
\end{tabular}

The next phase in the trajectory is the competence stage, and what Maria needs to gain in this step is the knowledge that will help decide whether Raif is the right man to make friends with, or perhaps, to be lovers. The competence stage can be suggested to initiate right after they meet and decide to make friends, which comprise the manipulation phase. The transition from manipulation to competence may not be considered so transparent. Nevertheless, when we check what happens between them right after Maria's decision statement "You do not know of me a lot, but I observed you for 15-20 days...Yes, we may well make friends" (p. 77), we can easily see that Maria and Raif start learning about each other. It is possible to make the analogy that it is Maria's game, the rules of which are established by her at the night they meet while Raif accompanies her to home, "do not care if we have quarrels" (p. 81), "it is all finished if you demand anything from me" (p.81). The next day, they get together as compromised. Maria welcomes Raif in front of her house "at half-past three in the afternoon" (p. 88). It is the second period they spend time and have estimation about themselves. They go to "a big garden with iron gratings" (p.91), and Maria keeps suggesting her thoughts clearly, which she believes will protect their relationship. Then, she asks Raif not to pity her even once, which is another rule that indicates the independent soul of Maria. Afterwards, they go to "a restaurant in the west part of the city" (p. 95) to eat out. Maria keeps her silence for some time and confesses that "she does not love Raif as well" as she could not do in the past (p. 96). Then she keeps her clarifications that she "desires a man, a true man to drag her without leaning on another source of power" (p. 98) and why she cannot love Raif but make a good friend with him to share experiences. Raif accepts this offer, continuing their date at another place, "Romanisches Kaffe" (p. 102).

After that day, "they start meeting and walking around every day" (p.105). Maria seems to find her best friend in her life. However, what is lacking in her soul is love, which she defines as "the love I wait for is different... It is to desire with all soul, body and everything" (p.107). Raif observes and senses in the later dates that although Maria limits herself to give hope for taking their relationship from friendship to dearness, "she is of conflicting feelings" (p.109) on how to behave Raif. This indicates that Maria is still looking for a sense of love with Raif, and she will try other ways to find it. From that moment on, Maria can be said to be at the performance stage. Raif further reflects his observation about this situation with these

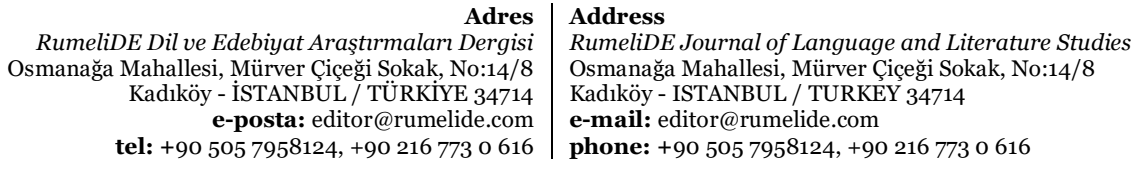


A semiotic observation of narrative trajectories in Madonna in a Fur Coat by canonical narrative schemas / 0. Büyükkarcı (pp. 345363)

statements: "Sometimes, she was showing so close interest as to seduce me" (p. 109), "she was also aware that our friendship bogged down due to the absence of further steps" (p. 109). In the late days of December, they "decide to be out together at New Year's Eve and dance" (p. 110) after Maria finishes up with work at Atlantic Pub. The night ends with "Maria's kissing Raif" (p. 116), who loves her very much, and their intercourse for the first time. In the morning, Maria starts speaking in an upset manner "What do you want more? Do you desire another thing? But I want, and I cannot reach any of them... I tried every remedy; but it is no use. You can be satisfied now! But what should I do?" (pp. 118-119). She desperately states that she is still not in love with Raif though tried everything including to sleep with him, and says, "they should not be in touch until they feel the need to see each other" (p. 120). After Raif leaves, Maria gets sick badly. She is taken to hospital. Raif, who has been looking for her curiously for five days, finds out she is at "Charlie Hospital" (p. 127). He cares her for 25 days there. Then, Maria asks Raif to take her home, saying, "you can look after me better" (p. 131). Raif waits by the side of Maria till late hours at night and comes very early in the mornings, reads bedtime stories to her. These errands become regular in time, and Raif is never dissatisfied with looking after the woman he loves. Maria, seeing Raif does all of these only for love, confesses "that she madly loves him too" (p.136), and this delay is because "people have secured the ability of trust from her" (p. 136). However, this happiness will not last long. Hardly does Maria think that she has attained true love when Raif says he needs to be back in his hometown because of his father's demise. Hearing this, Maria decides to leave Berlin before Raif does, and she goes to Prag. Her last words are, "I am going now, but whenever you ask, I can come, wherever you ask, I can come" (p. 140). This is the last time they see each other. The demise of Raif's father makes them leave and lose each other. Though Maria has found the man of her life, this lasts too short, which can be evaluated as a failure. However, the declaration of this and the other incidents is in the last part of the novel, which is the sanction stage of trajectory.

For some more time, Maria keeps exchanging letters with Raif, in which she says "she has something very nice to tell him" (p. 143), but he should wait to learn till she comes to Raif's hometown. However, Raif has to wait for "10 years to learn this happy news" (p. 144). Maria does not reply to Raif's letter, and Raif loses all her hope to be with her again. All of what happens to Maria, which is the sanction, is declared by Frau Van Tiedermann, who sees Raif after ten years in Ankara holding a little girl's hand. She recounts that "Maria died when her daughter's birth without telling anyone who is her daughter's father" (pp. 155-156).

\section{4 "Raif Efendi's father"}

It is the trajectory of Raif's father that triggers lots of events in the novel. Raif Efendi gives tiny but sufficient information on his father for understanding the frame of his narrative trajectory. "His father is from Havran" (p. 47) and "afraid of his son's aftermath when he witnesses young people murdered by both the enemy and brigands during the First World War" (p. 48). So, "he decides to send Raif to Istanbul" (p. 48), leaving him the school choice. This decision indicates the very first objective of Raif's father, which is to keep her son safe. After Raif spends some time in Istanbul in "The Academy of Fine Arts" (p. 48), then his father wants him to go to Germany "to learn soap production, especially the production of mis soaps" (p. 50). He clearly defines his aim in his letter to Raif: "if you learn this profession, I will reform and enlarge our soap factory and leave it to your administration. Thus, you can be happy and prosperous" (p. 50). With the decision to send Raif, his father would protect his son from harm and guarantee his life, depicting fatherly thoughts. From this insight, we can deduce the initiation of the trajectory of Raif's father.

Table 2.4: Canonical Narrative Schema of Raif's Father's Trajectory

\begin{tabular}{|c|c|c|c|}
\hline $\begin{array}{l}\text { Manipulation } \\
\text { (Contract) }\end{array}$ & $\begin{array}{l}\text { Competence } \\
\text { (Qualifying Test) }\end{array}$ & $\begin{array}{l}\text { Performance } \\
\text { (Decisive Test) }\end{array}$ & $\begin{array}{l}\text { Sanction } \\
\text { (Glorifying Test) }\end{array}$ \\
\hline Osi & $\begin{array}{r}\text { Adres } \\
\text { ebiyat Araşturmaları Dergisi } \\
\text { Mürver Çiçeği Sokak, No:14/8 } \\
\text { STANBUL / TÜRKİYE 34714 } \\
\text { oosta: editor@rumelide.com } \\
7958124,+90 \text { 216 } 773 \text { o } 616\end{array}$ & \multicolumn{2}{|c|}{$\begin{array}{l}\text { Address } \\
\text { RumeliDE Journal of Language and Literature Studies } \\
\text { Osmanağa Mahallesi, Mürver Çiçeği Sokak, No:14/8 } \\
\text { Kadıköy - ISTANBUL / TURKEY } 34714 \\
\text { e-mail: editor@rumelide.com } \\
\text { phone: +90 505 7958124, +90 } 216773 \text { o } 616\end{array}$} \\
\hline
\end{tabular}




\begin{tabular}{|c|c|c|c|}
\hline $\begin{array}{l}\text {-What manipulated him is the } \\
\text { desire to protect Raifs life and } \\
\text { give him a chance to make his } \\
\text { life by transferring the soap } \\
\text { factor after Raif learns the } \\
\text { soap production process } \\
\text { (p.50). }\end{array}$ & $\begin{array}{l}\text {-Raif starts an } \\
\text { apprenticeship in a soap } \\
\text { factory that belongs to a } \\
\text { Switzerland group (p. } \\
\text { 53), and he goes there to } \\
\text { learn this profession } \\
\text { despite interruptions and } \\
\text { the love affair that brings } \\
\text { retardation (p. 62). }\end{array}$ & $\begin{array}{l}\text {-Raifs learns his father } \\
\text { died (p. 137) and gets } \\
\text { back to his hometown. } \\
\text { However, Raif's father did } \\
\text { not leave the soap factory } \\
\text { to him as promised. So } \\
\text { Raif declares that he sold } \\
\text { the factory to his sisters' } \\
\text { husbands before he dies } \\
\text { (pp. 142-144). }\end{array}$ & $\begin{array}{l}\text { - Raif cannot be } \\
\text { successful in farm } \\
\text { work and becomes a } \\
\text { civil servant in } \\
\text { Balıkesir, and then he } \\
\text { starts working at the } \\
\text { company in Ankara, } \\
\text { which he currently } \\
\text { works (p. 148). }\end{array}$ \\
\hline \multicolumn{4}{|l|}{ Modality } \\
\hline $\begin{array}{l}\text { Convincing/Directing } \\
\text { Wanting-to-do } \\
\text { Having-to-do }\end{array}$ & $\begin{array}{l}\text { Being-able-to-to } \\
\text { Wanting-to-do } \\
\text { Knowing-how-to-do } \\
\text { Having-to-do }\end{array}$ & To-do & $\begin{array}{l}\text { Knowing about } \\
\text { action/subject }\end{array}$ \\
\hline
\end{tabular}

Raif "makes necessary preparations in a week and departs to Germany by train over Bulgaria" (p. 51). This is the competence stage in which he is supposed to learn the soap production process. However, he confesses to being disinterested in his father's objectives from the first time he has known to be sent to Germany: "I was not considering this much, but guessing that I would learn a foreign language, read books in this language, find people that I had met in novels there" (pp. 50-51). Indicating that this comes true, Raif, "as if he forgot why he came to German" (p.52), spends time reading books and idling there and intentionally falls behind his true aim. Nevertheless, no matter how slowly he behaves, he does not want to be a complete liar against his father and starts an apprenticeship on soap production "in a facility that belongs to Switzerland group" (p.53). However, it is not so fast for Raif to learn soap production, and what is more, he falls in love with an artist in the name of Maria Puder, who has become Raif's primary source of interest for two years till he has to be back to his hometown due to his father's demise. Despite interruptions, "he intends to restart his apprenticeship" (p. 62) in the same factory and gains some necessary information on soap production. However, he only goes there "before afternoon" (p. 105), which can be assumed a little late.

At the performance stage, the audience is supposed to see whether Raif can get the administration of the soap factory to be "a useful man" (p. 50), which is as his father wishes. He can be said to get some information on soap production in German. Although he becomes a retarding figure in his father's trajectory, it cannot be suggested that only Raif or his love affair hinders his father's trajectory. One day, Raif get a telegraph from one of his sister's husband, saying, "your father died, I sent the carfare, be here immediately" (p.137), and he gets back to his hometown in four days. When he comes, "he is not welcomed" (p. 142) and learns that "his father portioned the inheritance" (p. 142), and "the two soap factories are sold to one of the sister's husbands by his father" (p. 143). When we look at what Raif declares as a narrator, we understand at first glance that Raif's father excludes Raif from the promised parts of his inheritance willingly, and this means Raif's father intentionally aborted his trajectory. However, there is much doubt about the incidents, and Raif interprets them as "it seems there was big treachery in my absence utilizing my father's illness, my mother's helplessness and my sisters' cowardice” (p. 144). So, he blames his sisters' husbands for being excluded from his father's fruitful farmlands, "a great deal of money and gold" (p. 143), and soap factories. Whatever the truth is, what is blindly obvious is that Raif father's trajectory fails. Raif

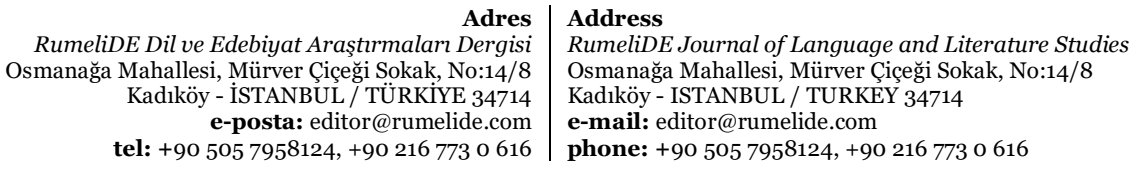


A semiotic observation of narrative trajectories in Madonna in a Fur Coat by canonical narrative schemas / 0. Büyükkarcı (pp. 345363)

first becomes "a civil servant in a company in the city centre" (p. 148), then starts working in Ankara in the current company instead of being a tradesman.

\subsection{Husbands of Raif's sisters}

It is the trajectory of Raif's sisters' husbands towards which we may have undertone to missing. This is because this trajectory has a mainly hidden form whose graduations are not recounted, but only be guest with the help of declaration of consequences learnt by Raif after his late arrival to his hometown for his father's demise. Besides, this trajectory can be named as a counter trajectory against that of Raif's father. As stated earlier, Raif's father sends his son to Germany to learn soap production, at the end of which he wants to carry over the soap factory. However, when Raif is back from Germany, he learns that "his father sold the two factories to one of his sister's husband" (p. 143), and he can find neither the money earned from this selling nor the golds of his father. These incidents all bring about suspicion on Raif's side, which I believe cannot be just a coincidence. The strong possibility of Raif's sisters' treachery pushed Raif to confess his suspicion in these words: "it seems there was big treachery in my absence utilizing my father's illness, my mother's helplessness and my sisters' cowardice” (p. 144). Besides, it is that possibility that makes it worth evaluating the earnings of Raif's sisters' husbands as a trajectory designed in advance. Neither Raif's sisters nor their husbands are called with their names, and the audience sees one of them mentioned for the first time in the "telegraph" informing Raif about his father's demise (p. 137). Below is the table depicting the phases of their 'possible trajectory'.

Table 2.5: Canonical Narrative Schema of the Trajectory of Raif's Sisters' Husbands

\begin{tabular}{|c|c|c|c|}
\hline $\begin{array}{l}\text { Manipulation } \\
\text { (Contract) }\end{array}$ & $\begin{array}{l}\text { Competence } \\
\text { (Qualifying Test) }\end{array}$ & $\begin{array}{l}\text { Performance } \\
\text { (Decisive Test) }\end{array}$ & $\begin{array}{l}\text { Sanction } \\
\text { (Glorifying Test) }\end{array}$ \\
\hline $\begin{array}{l}\text {-The desire to take possession of } \\
\text { Raif's father inheritance possibly } \\
\text { trigger the husbands of Raif's } \\
\text { sisters. And Raif is their primary } \\
\text { opponent in their quest. }\end{array}$ & $\begin{array}{l}\text {-Raif is suspicious } \\
\text { that to get a } \\
\text { productive part of the } \\
\text { inheritance and his } \\
\text { father's money, his } \\
\text { sisters' husbands } \\
\text { utilize } \\
\text {-Raif's absence } \\
\text {-Raif's father's illness } \\
\text {-Raif's mother's } \\
\text { helplessness } \\
\text {-Raif's sisters' } \\
\text { cowardice (p. 144). }\end{array}$ & $\begin{array}{l}\text {-Raif's learns his father } \\
\text { portioned his } \\
\text { inheritance before } \\
\text { dying and sold the soap } \\
\text { factories to one of his } \\
\text { brothers (pp. 142- } \\
\text { 144). }\end{array}$ & $\begin{array}{l}\text {-Raif cannot be successful } \\
\text { in farm work and becomes } \\
\text { a civil servant, and then he } \\
\text { has to sell the infertile } \\
\text { farmlands to his brothers } \\
\text { in law to pay his debt (p. } \\
\text { 148). }\end{array}$ \\
\hline \multicolumn{4}{|l|}{ Modality } \\
\hline $\begin{array}{l}\text { Convincing/Directing } \\
\text { Wanting-to-do/Having-to-do }\end{array}$ & $\begin{array}{l}\text { Being-able-to- } \\
\text { do/Wanting-to-do } \\
\text { Knowing-how-to- } \\
\text { do/Having-to-do }\end{array}$ & To-do & $\begin{array}{l}\text { Knowing about } \\
\text { action/subject }\end{array}$ \\
\hline
\end{tabular}

No matter how unnarrated the initiation of the trajectory of sisters' husbands, it is clear that they have a desire to take possession of Raif's father inheritance. Raif is their primary opponent in their quest, so it can

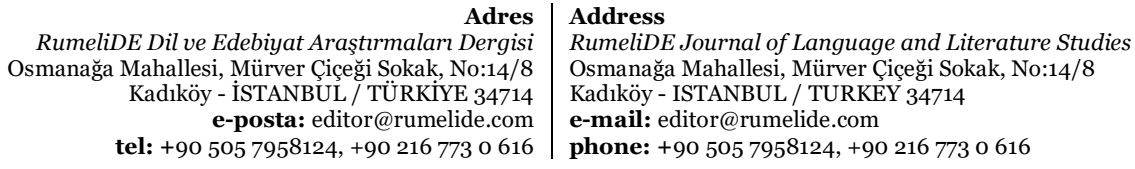


be deduced that his absence (nearly two years) is one of the primary helpers to them, and they make use of it as an advantage at the competence stage. The other helpers to the husbands of Raif's sisters are the illness of Raif's father and the helplessness and illiterateness of his mother. There are some possibilities on how they utilized these factors at the performance stage of their trajectory. For instance, Raif's mother confesses that "his brothers in law never left his father alone in his last days" (p. 143), and they may have had the sales agreement of the factories signed by Raif's sick father and learnt the place of his money and gold where he buried. The other possibility is that they may have done the same thing to Raif's mother as she is illiterate and unaware of what she was signing, then told a lie about what had happened to Raif. When considering that Raif achieves arriving his hometown seven days later, the second scheme seems quite possible. Lastly, for the sanction part, it is arguable that Raif's brothers-in-law buy the infertile farmlands that Raif has to sell to pay his debt, which compose the rest of the inheritance that they had to give Raif (p. 148).

\section{Conclusion: Interpretation of the Data}

As stated in the introduction part, the aim of this study is to reveal the narrative organization of Madonna in a Fur Coat. Till now, five different actors' trajectories have been analyzed, using canonical narrative schemas, serving our purpose. These schemas not only subsume the logical graduations of events but also facilitate the observation them in that we can see the actors' roles in the improvement and completion parts of trajectories. What is next is to clarify positive and negative interrelations between the trajectories and the interferences of actors with them, which represents another purpose of the study. Doing this will enhance the provision of the aforementioned insight into the authorial skills of Sabahattin Ali, inner structure of his work and the methodology used in the study.

\subsection{The temporal hierarchy and relationship between trajectories}

Although the analysis part comprises investigating the actors' trajectories in a way that can be considered random, it should be underlined that four of the trajectories transpire at the same temporal plane; one of them is different. The trajectories of Raif Efendi, Maria Puder, Raif's father and Raif's brothers-in-law takes place in the same timeline, but the narrator's trajectory is situated in such an omniscient position in terms of time and purpose that it can control the initiations, improvements and outcomes of others. In the below figure, the temporal hierarchy and the cause-effect relations between the trajectories are presented.

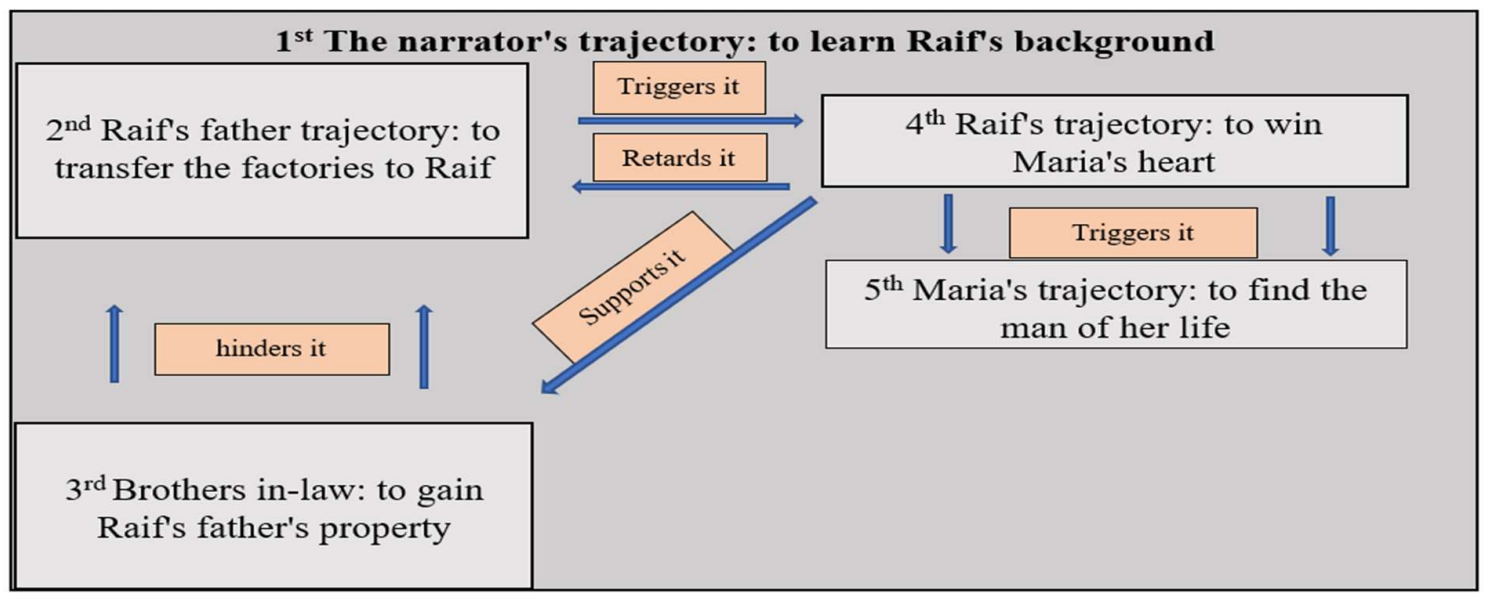

Figure 3.1: Temporal Status and Interrelations of Actors' Trajectories

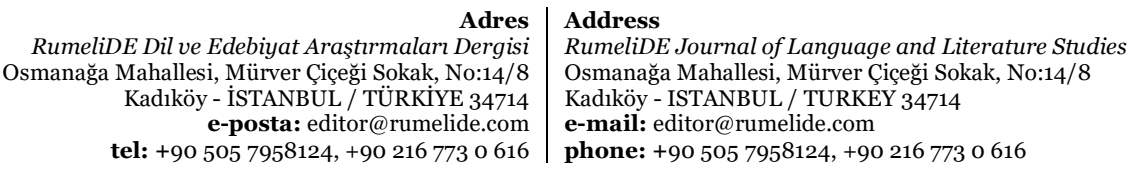


A semiotic observation of narrative trajectories in Madonna in a Fur Coat by canonical narrative schemas / 0. Büyükkarcı (pp. 345363)

The narrator's trajectory ranks first and is on top of all other trajectories for its presence in time and function. This is because the narrator's primary purpose is to learn the background of Raif Efendi, who is one of the most influential people in his life (see Table 2.1). Thus, his trajectory can be said to be as comprehensive as to give the chance to witness each succession of events that happened in the past. The other trajectories, Raif's father, Raif's brothers-in-law and Maria Puder, are on the the same temporal plane as far as their realization is concerned.

Concerning the interrelations between the five trajectories, we need to consider the ones that transpire simultaneously. These are Raif's, Raif's father, Raif's brother-in-law and Maria's trajectories. Among them, the two trajectories, those of Raif's father and brothers-in-law, represent anti-narrative trajectories as their achievements depend on each other's outcome. As Yücel states (2015), the achievement of one of them means the other's failure, or vice-versa. So, the accomplishment of Raif's brothers-in-law to obtain the factories, and possibly the money from the sale and Raif's father's gold, indicates the failure of Raif's father (see Tables 2.4 and 2.5). Another type of relationship between the trajectories is that they trigger each other. For instance, that Raif's father sends his son to Germany to expertise in soap production is the initiation point for Raif to find the woman of his life and his pursuit of her. Besides, it is Raif's love at first sight and his trajectory that attracts Maria Puder, in other words, that triggers her trajectory. Raif's trajectory has two other effects on others. For instance, it retards his father's goals, whereas it supports the trajectory of his brothers-in-law by helping them buy time, perhaps for persuading Raif's father on selling the factories or telling the places where he buried his money and gold.

\subsection{Cognitive senders}

What is remarkable in all five trajectories is that they have cognitive senders, or we may say, manipulators. Accordingly, all five senders are composed of 'some desires of the subjects of the quests. For instance, the thing triggering the narrator is 'the desire to learn Raif Efendi's past' (see Table 2.1). Raif's manipulator is 'the desire to steal Maria's heart, or shortly, love' (see Table 2.1). The sender in Maria's trajectory is 'the desire to find the man her life and her attempt to attain it via Raif's love' (see Table 2.3). Raif's father's sender is 'the desire to protect her son from harm and make him a useful man' (see Table2.4).

\subsection{The trajectories ending with success vs failure}

The two of five trajectories can be seen to end with success, but the others with failure. At the end of the novel, the audience is informed that Maria had died just after she gave birth to her child, indicating both Raif and she lost each other. Additionally, the declaration of Raif's father demise shows his failure as well, whether he intentionally excluded Raif from inheritance or by the persuading treachery of his daughter's husbands. Only the narrator, who wants to learn Raif's background, and husbands of Raif's sisters end their trajectories with success.

\subsection{The key events that bridges the trajectories}

The last title for the conclusion part subsumes the key events that link or affect the five trajectories. More clearly, what is meant by this heading is the presence of incidents that are critical to the successions of others in the novel. Though this issue is quite disputable and open to commend, I should say two events must be revealed in terms of their effects on the novel's plot composition. These are respectively Raif's being sent to German by his father and his father's demise. To understand better the functions of these two events,

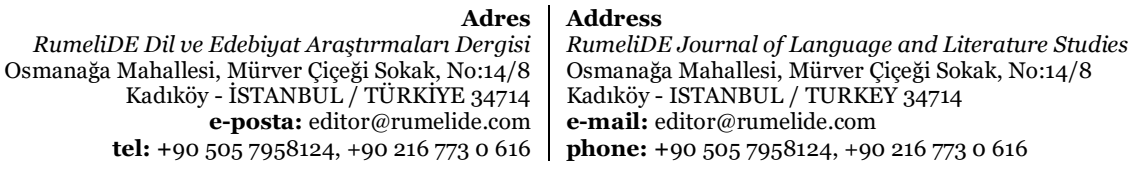


we can consider what happens after them. The following figure comprises the scenario after Raif is sent to Germany.

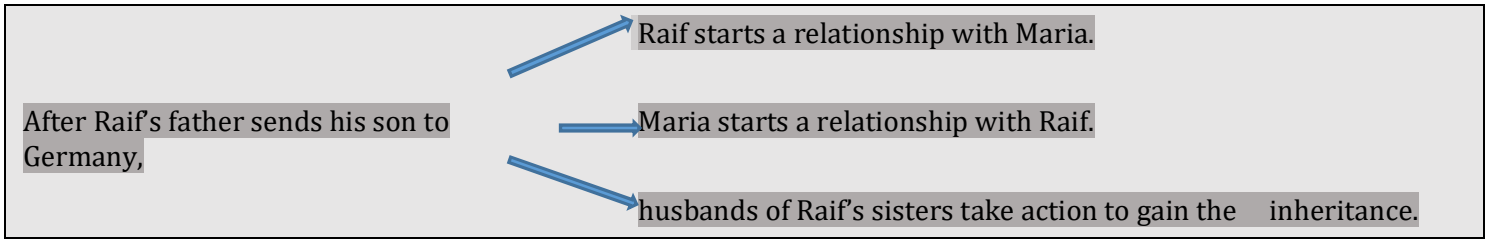

Figure 3.2: The Events After Raif's Father Sends His Son to Germany

As shown in the figure above, Raif's father's action takes an important place in the activation of others. What is surprising is that his death equally affects the initiation of other successive incidents. These incidents all compose the sanction phases of four actors' trajectories, which means his demise triggers the concluding events of trajectories. The below figure indicates what happens after his demise.

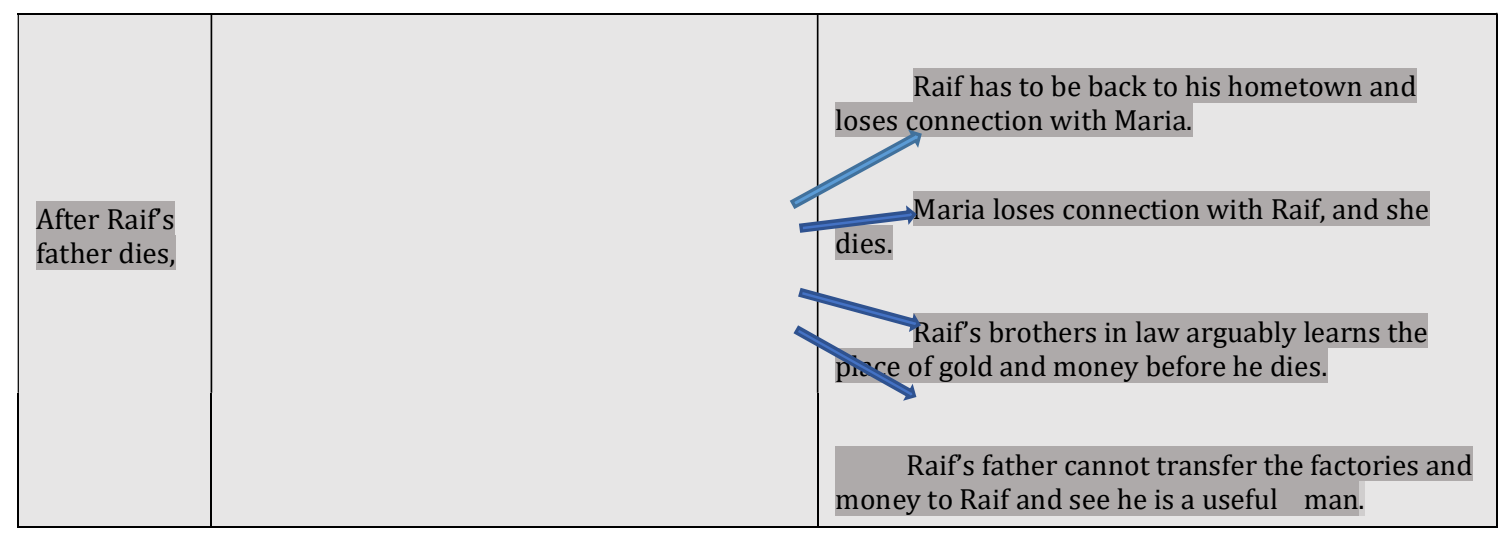

Figure 3.3: Events That Happen After Raif's Father Dies

As evident in Figure 3.3, Raif 's father demise results in the flourishing of outcomes of nearly all trajectories. When we consider Raif's trajectory, only after he hears the words 'I love you too' from Maria, which he has long waited, he has to return to his home town for his father's demise, resulting in the loss of connection with Maria. However, we would probably give quite a different answer to a question like 'what if Raif's father did not die or die later?'. Raif would possibly be back to his hometown with Maria, tell his father that he has become qualified enough to take administration of the soap factories and prevent the sale of them to his brother-in-law, or was able to learn the place of his father's gold and money including the one from the sales even if he could not stop it. Besides, Maria could still be alive if Raif did not return home because Raif would not let Maria give birth to a child that will claim her life. So, these all tragedy-like events succeeding after the demise of Raif's father indicate the skillful intentionality of the author Sabahattin Ali in plot construction.

\section{Acknowledgement}

This article was presented as a proceeding in the $3^{\text {rd }}$ International Rumeli Congress on 26-27 July, 2021.

\section{References}

Ali, S. (1943). Kürk Mantolu Madonna (Madonna in a Fur Coat). Istanbul: Remzi Kitabevi Güven.

Ali, S. (2017). Kürk Mantolu Madonna (Madon in a Fur Coat). Istanbul: Yapı Kredi.

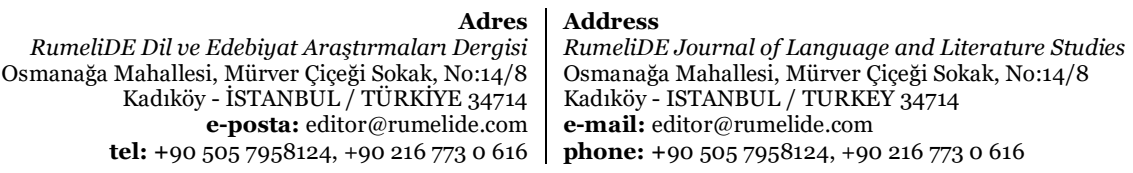


A semiotic observation of narrative trajectories in Madonna in a Fur Coat by canonical narrative schemas / 0. Büyükkarcı (pp. 345363)

Bezirci, A. (2007). Sabahattin Ali. Istanbul: Evrensel Basım Yayın .

Budniakiewicz, T. (1992). Fundamental of Story Logic: Introduction to Greimassian Semiotics. Amsterdam: John Benjamins Publishing Company.

Büyükkarcl, O., \& Bulut, T. (2018). On Meaning Production Process in Short Stories: A Semiotic Approach to Hwan Sunwon's "Cranes". International Journal of Language Academy 6(5), 230-251, http://dx.doi.org/10.18033/ijla.

Greimas, A. J. (1966). Semantic Structurale. Paris: Larousse.

Greimas, A. J. (1988). Maupassant: The Semiotics of Text (Trans. by Paul Perron). Amsterdam: John Benjamin Publishing Company.

Greimas, A. J. (1989). On Meaning. New Literary History, 20(3), 539-550.

Greimas, A. J., \& Courtes, J. (1982 [1979]). Semiotics and Language: An Analytical Dictionary. Bloomington: Indiana University Press.

Günay, D. (2018). Bir Yazınsal Göstergebilim Okuması Kuyucaklı Yusuf [A Literary Semiotic Reading of Kuyucaklı Yusuf]. Istanbul: Papatyabilim.

Hebert, L. (2020). An Introduction to Applied Semiotics: Tools for Text and Image Analysis. New York: Routledge.

Hirik, S. (2020). Türkçede Bağdaşıklık ve bağdaşıklık Unsurları: Kürk Mantolu Madona İncelemesi. Nevşehir Hacı Bektaş Veli Üniversitesi SBE Dergisi, 10(1), 221-238.

Kalelioğlu , M. (2018a). A Literary Semiotics Approach to the Semantic Universe of George Orwell's Nineteen-Eighty Four. Newcastle upon Tyne: Cambridge Scholars.

Kalelioğlu, M. (2018b). Analysis of Duha Koca Oglu Deli Dumrul Narrative within the Framework of Literary Semiotics. Turkish Studies, 13(5), 229-256.

Kalelioğlu, M. (2020). Yazınsal Göstergebilim: Bir Kuram Bir Uygulama. Istanbul: Seçkin.

Karakuş, M. (2010). Bildungsmigration nach Deutschland und ihre Auswirkungen auf die Literatur: Sabahattin Alis Roman Die Madonna im Pelzmantel. Türkisch-deutsche Studien, No 2010, 187-195.

Kıran, Z., \& Kıran, A. E. (2011). Yazınsal Okuma Süreçleri (The Process of Literary Reading). Istanbul: Seçkin.

Kıran, Z., \& Kıran, A. E. (2018). Dilbilime Giriș (Introduction to Linguistics). Istanbul: Seçkin.

Landowski, E. (2015). The Greimassian Semiotic Circle. In M. Grishakova, \& S. Salupere, Theoretical Schools and Circles in the Twentieth Century Humanities (pp. 84-96). New York: Routledge.

Martin, B., \& Ringham, F. (2000). Dictionary of Semiotics. London/New York: Cassell.

Martin, B., \& Ringham, F. (2006). Key Terms in Semiotics. London/New York: Continuum.

Moran, B. (2001). Türk Romanına Eleştirel Bir Bakış (A Critical Perspective to Turkish Novel). Istanbul: İletişim.

Okur, E. (2017). Çok Partili Dönem Türk Romanı (Turkish Novel in Multi-Party Period). Hece, 85-102.

Öztokat, N. T. (2005). Yazınsal Metin Çözümlemelerinde Kuramsal Yaklaşımlar (Therotical Approaches in the Analysis of Narrative Texts). Istanbul: Multi-Lingual.

Rifat, M. (2011). Homo Semioticus ve Genel Göstergebilim Sorunları [Homosemioticus and General Problematics of Semiotics]. Istanbul: Yapı Kredi.

Rifat, M. (2014). Göstergebilimin ABC'si (ABC of Semiotics). Istanbul: Say.

Vardar, B. (2001). Dilbilimden Yaşama Yapısalcılık (Structuralism from Linguistics to Daily Life). Istanbul: Multilingual.

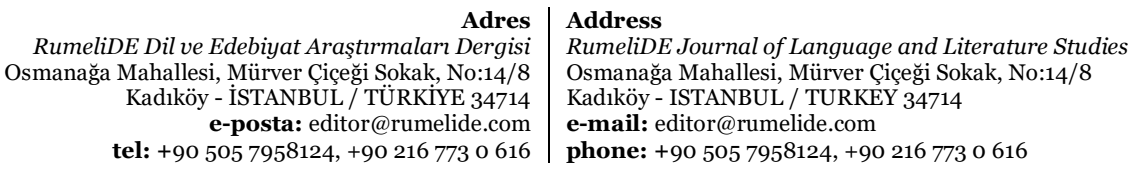


Yıldız, F. U., Tekin, S. Ç., Öztürk, A. E., Düzdemir, Ş., \& Soyşekerci, G. (2018). Anlatıcının Kiplikler Açısından İncelenmesi: Kürk Mantolu Madonna'daki Anlatıcının Kiplikleri. Dokuz Eylül Üniversitesi Edebiyat Fakültesi Dergisi, 5(1), 67-87.

Yücel, T. (1999). Tartışmalar (Discussions). Istanbul: Yapı Kredi.

Yücel, T. (2001). Genel Gösterebilim (General Semiotics). In E. Onat, \& S. Ö. Yıldırım, Göstergebilim Tartışmaları (Discussions on Semiotics) (pp. 9-14). Istanbul: Multilingual.

Yücel, T. (2012). Eleștiri Kuramları [Theories of Criticism]. Istanbul: Türkiye İş Bankası.

Yücel, T. (2014). Söylemlerin İçinden (Through the Discources). Istanbul: Alakarga.

Yücel, T. (2015). Yapısalcılık [Structuralism]. Istanbul: Can Sanat.

Yüksel, A. (1995). Yapısalcılık ve Bir Uygulama: Melih Cevdet Anday Tiyatrosu (Structuralism and an Application: Melih Cevdet Anday Drama). Ankara: Gündoğan.

RumeliDE Dil ve Edebiyat Araştırmaları Dergisi Osmanağa Mahallesi, Mürver Çiçeği Sokak, No:14/8 Kadıköy - ÍSTANBUL / TÜRKIYE 34714 e-posta: editor@rumelide.com tel: +90 $5057958124,+902167730616$
Address

RumeliDE Journal of Language and Literature Studies Osmanağa Mahallesi, Mürver Çiçeği Sokak, No:14/8

Kadıköy - ISTANBUL / TURKEY 34714

e-mail: editor@rumelide.com

phone: +90 505 7958124, +90 2167730616 